講識

\title{
工具銅の熱處理要領 (XIV)
}

\section{大和久重 雄*}

\section{（5）蟯入の際に生ずる缺届とその對策}

高速度喘の燒入の際に生ずる缺陷の主なるるのは粗粒 北, 過熱, 酸化, 脫炭, 渗炭, 燒割れ, 燒曲り等である.

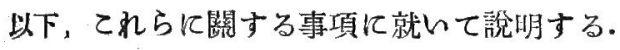

\section{(a) 暁入高速度銅の結晶粠度}

結晶粒度 (Grain size) \&鋼の燒入性，機械的性啠篮 几大なる關係老もつてわるために，近特非常に關心をを

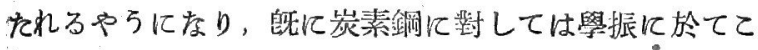

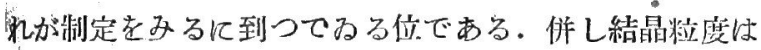

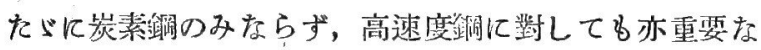
る問題である。

從柬，燒入した高速度銅の良否老肉眼的几判定する方 法としてはその破面を检查し，てれが繳密をるものを以 つて優秀なりとし，又所謂結晶粒が細かければよいとさ れてわたのである. 然るに結晶粒が細かくありさへすれ

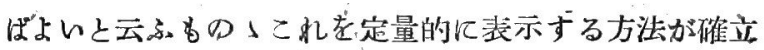

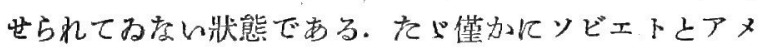

すのである(A.S.T.M. 式).

アメリカに於はるものは燒大した高速度銅を先づ 4 $10 \% \mathrm{HNO}_{3}$ アルコール溶液か又は $\mathrm{HCl} \cdots 10 \% ; \mathrm{HNO}_{3} \cdots$

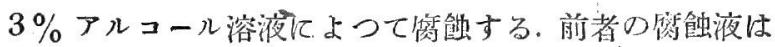
一般に用ひられておるものだあるが，てれによつては焼

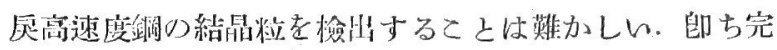
成バイトとか刃淔用中のバイ下が折損したやろを場合 て果してどれ位の結晶棹度りものであアたかと云ふやう なととを試驗する必要のあるときには都合が惡い。然る 飞後者の應蝕液は $\mathrm{HCl}$ が $10 \%$ 添加せられてねるので, オーステナイトの結晶粒界を强く笍触し, 而为同時てマ

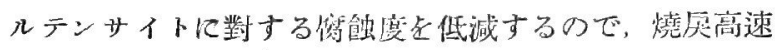

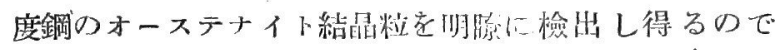
ある。

“ェッチングの要领は試片を研祭後, 上記の留蝕液に

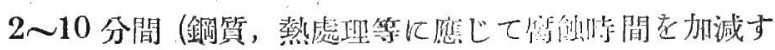

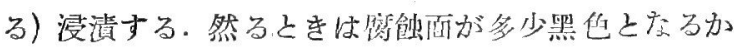

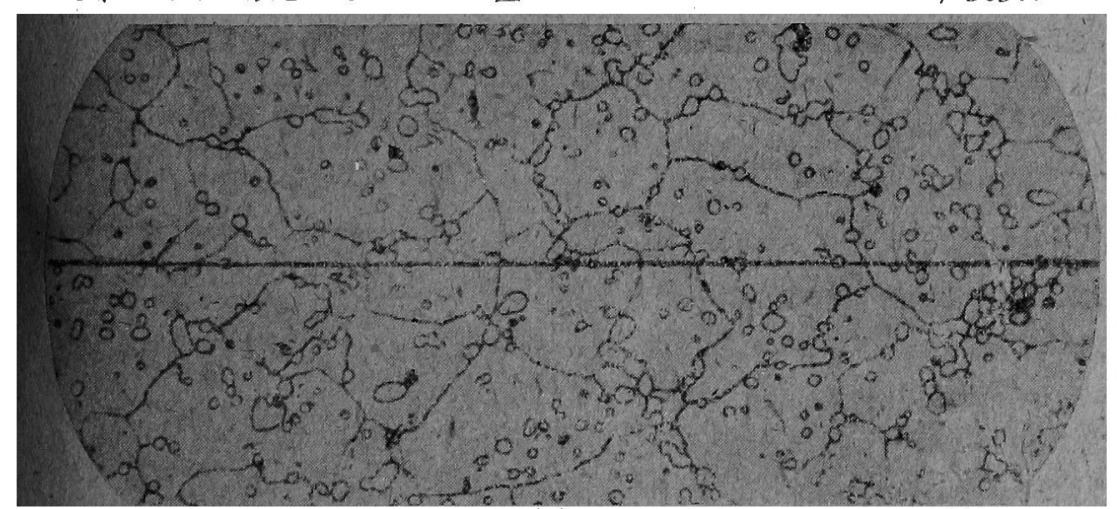

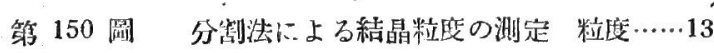

らこ礼を签く琢磨する。この再环磨に よつてオーステナイトの絔晶粒が非営 によく現は狄てくるのであつて，特に

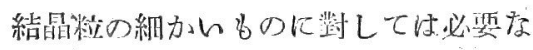
る操作でする。

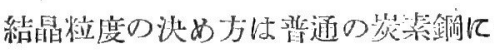
龂して探用せられてるるお法でもよい が，特汇高速度錩小絬鼠粒が紹かいか ら賞万分割法 (Intercept method) に

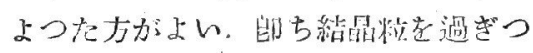
て或ろ一定長の線分を引き，乙の線に

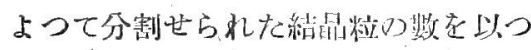

リカに於ててれが测䇥佧の一試案が提示せられてるるに 過ぎい。次にこれを紹介しよう。

ソビェトれ於けるものは高速虔细試片として $10 \times$

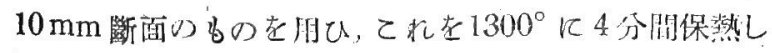
そ後油燒入在行ひ，倍卒 250 にて鏡檢し，1”×1”の视

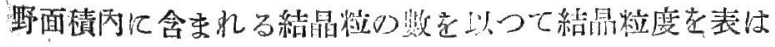

\section{* 践道技術研究所}

$\times 1000$

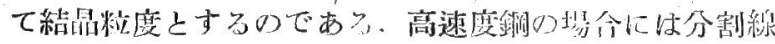

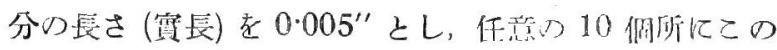

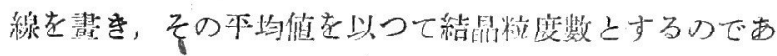

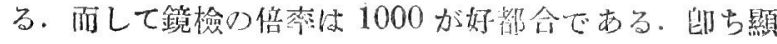
微鏡下に於ては $0.005^{\prime \prime} \times 1000=5^{\prime \prime}$ 長の線分によつて 過ぎられる結晶粒の數孛調べればよんのである。

嘪際間題としては顯微鏡の接腿鏡の視野が倍率 1000 のときに 5”值德となるやらに調節した多の在月ひ，而 
もとれに一本の直徑線索刻しをるのを使用すれば至極簡 單に $5^{\prime \prime}$ 線分 (實唇 $0.005^{\prime \prime}$ ) 几上る分制結晶粒の数を 讀みよることが出來る，而もこれを任意の個所に 10 回 施行すれば 10 個所の平均䛧が容易に求まることななる。

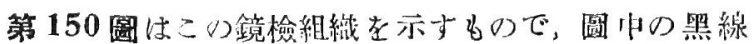
が $5^{\prime}$ 辰の分制線である。この試片は熙線によつて 13 個の結晶粒が分割せられてるるので，結晶粒度は 13 と云心ことになる。

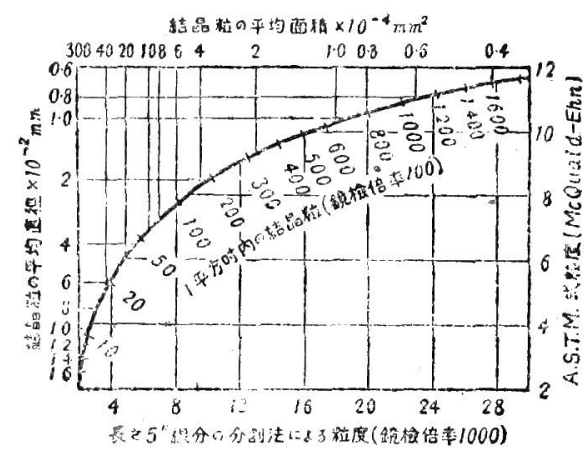

第 151 鱼 分割法による結晶粒度と他の 測定方法による粒度との關係
第 151 圖

はこの分割 法による結 晶粒度數己 他の测定㳂 によるもの 之の比較圆 である。即 方高速度鍓 の如を高合

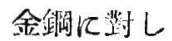

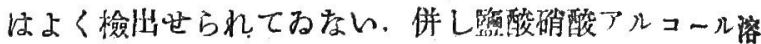

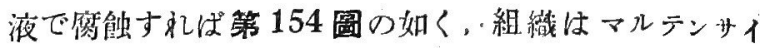
トであるが，オーステナイトの結晶䊀がよく現はれてる る.第 155１58 圆は燒戻高速度制つそれぞれ異なっ結 晶粒度の組織寺示すものである。

一般に高速度銅は結晶粒の細かいるの流鞄で，高 溫硬度は小でする．熱傳導率は結晶粒度によつて餘り影 響せられない，切削能力の點から云へば密る結晶粒の粗

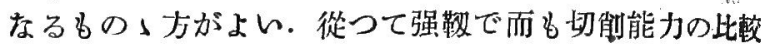
的良好なるものと云へば結晶粒度に自ら一定の限度を生 じてくる.この最適なる結晶粒度は銅質及び用途によっ て多少變化するもので，例人ばバィトに對しては結晶粒 度 10,タップ類に對しては 18 がよいと云はれてるる。

高速度鋼のオーステナイト結晶粒の大んさに影響する ものは燒入溫度，燒入保持時間，爐內朵圈の三つである。

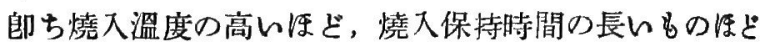
又爐內ガスの $\mathrm{CO}_{2} \%$ の多いもの压ど結晶粒は粗大とな る. 又高速度鋼中の複炭化物の多いもの度ど結晶粒の粗

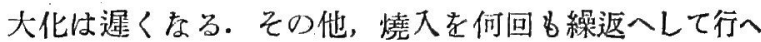

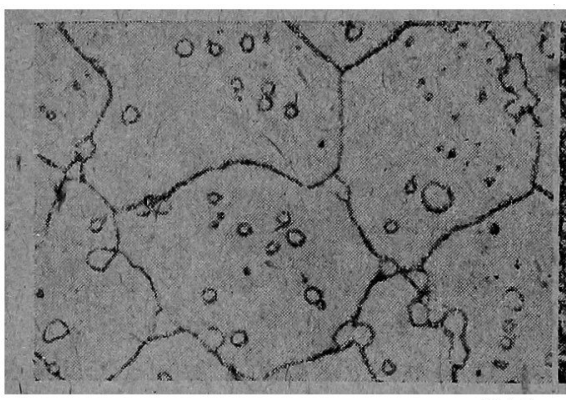

第 152 悯 $\times 1000$

确酸アルコール溶夜旡能 (燃入組織) 結晶粒度 $\cdots 10$

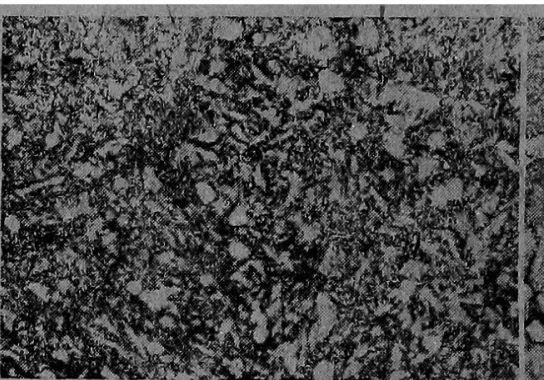

$\times 1000$

第 153 阙 筙 152 團の燒戻組緎确酸 アルコール卧液原感 結晶粕度…10

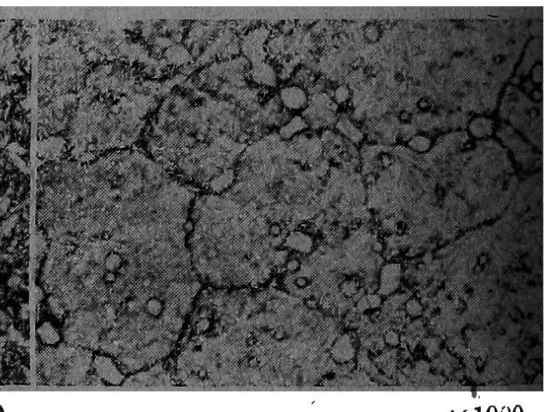

$\times 1000$

第 154 圆第 153 疅を監酸硙酸アル コール溶液歷鰠 䋨昆精陵…10

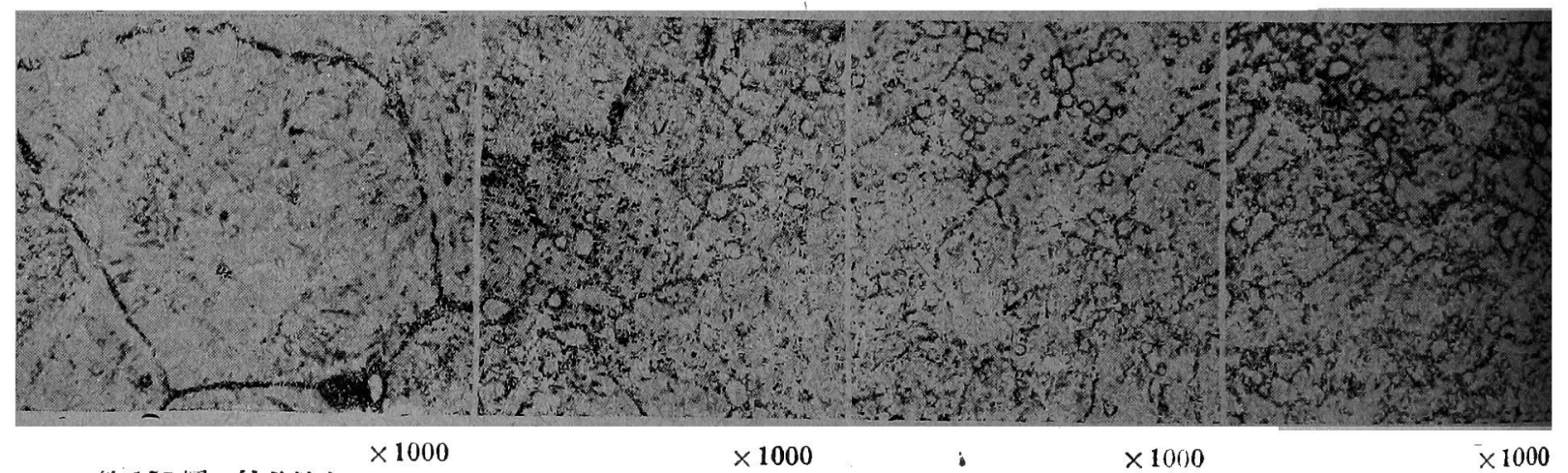

第 155 闻间 結晶粒度 $\cdots 5$ 第 156 國 結晶粒度 $\cdots 10$

第 157 圖 結晶粒度…15

第 158 圆 結晶数度...20

てはこの分割法が最も逈してるることが判る。

第 152 圖は燒入高速度錩老硝酸アルコール溶液によ つて憸出した場合の結晶粒で，上述の分割法による粒度 数 10 のものである.第 153 園はてれを焼戻したものを 硝酸アルコール溶液で鹪刢したもので，圖の如く結晶粒
ば結晶粒が粗大となり，遂にはフイッシュ、スケールを 示すやらになる・フイッシュ・スケールに關しては次項 老參照せよ。

(b) フイッシュ・スケール (Fish scale)

フイッシュ、スケールとは燒入した高速度鋼け破面に現 


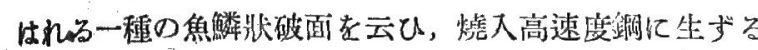
䊎陷の一つである.フイッシュ・スケールを生じを破面は 刃大理石狀比見えるとてろから Marble fracture 若 しくは Flaky fracture とも云は扎てみる.第 159 圖は 18-4-1 型高速度錩に現はれたフイッシェ.スケールを 示すもので，又第 160 圖はこれが顯微鏡組織である。 郎ち圖より明らかなる如く、フイッシュースケールはマク

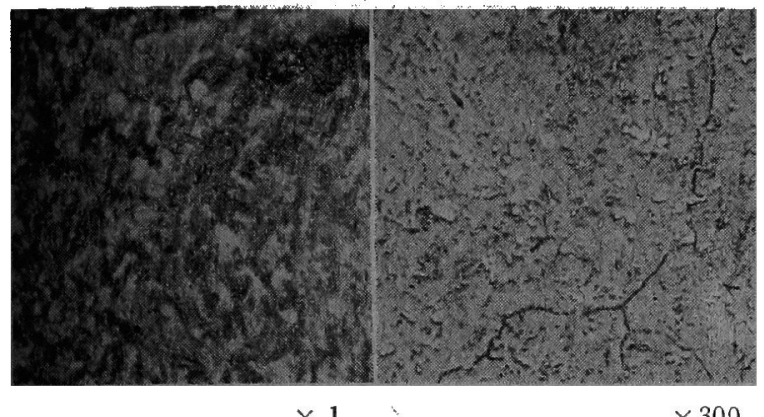

$\times 1$

第 159 圖 18-4-1 型高速度 鋼に現はれたフイッシュ・ス ケール (破面)

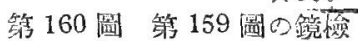
組織（䴡入組機）(大和久)
口的には魚䚬狀破面であるが，ミク口的にはオーステナ イト結晶粒の異常成辰に基づくものであることが制る。

一般にフイッシュ・スケールは中間焅政を行はずに攚 入を2 3 回繰返*した場合とか，又心火造品を燒鈍 せずにそのま〉燒大しを場合などに多く現はれる現象で 低 W 高速度鋼に特に著し々，色々試驗した結果によれ ばフイッシュ・スケールは燒入前の熱處琶又は機械的加 エによつて歪菂藏した高速度鋼が，その後の燒入によつ て生ずる一程の Grain growth,であるととぶ制つた・而 してての歪はオーステナイト狀態ひときに生じをものに 限られるのであつて，ての歪を受けたオーステナイトが

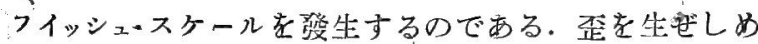
る原因には熱的のものと機械的のbのとの2 程がある。

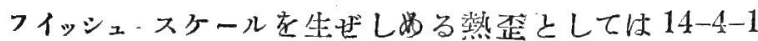
型高速度銓に對しては $800^{\circ}$, からの空中放泠程度，184-1 型高速度鋪に於ては $1150^{\circ}$ から空中放冷した程度 のものであり，機械的歪としてはオーステナイト狀態に 於ける變形に起因するものである。てれらの歪は试片の 中心部に於て大であるからフイッシュ・スケールもての 部分に生じ易々。

而してフイッシュ・スケールは 14-4-1 型蓜速度铜の

*但し呿入の際，䧕片が $200^{\circ}$ 以下に泠えなければ加熟泠 却を 10 回以上繰返していフイッシュ・スケールは墢生

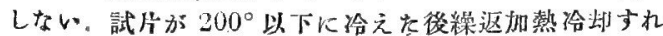
ぱフィッシスタール独生する。

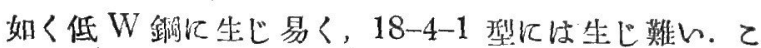
れは複装化物の多少がフィッシュ・スケールの發生を 防止する結果と考へられる。恰度, 装素洋に於て Grain growth がパーライトや粒师セメンタイトの传在によつ て防止せられるのと同橙である。而もての妨害物走全部 オーステナィト中に固溶せしめるには，より高い淄度に 加熱しなければならぬから 18-4-1 型の方がフイッシュ。 スケールを生ぜしめるに必荘疗與歪溫度が高いので ある。

猶, 爟入溫度が與歪溫度よりも低い量合にはフイッシュ スケールを生ずるてとは存い。而して䙺入前の歪が 大なる㭱ど，低い溫度加らの炶大でフイッシュ・スケー 儿を生ずるやらになる。メよぐイトなどをグラインダ 研磨によつて成北するてとがあるが，ての際にもての部 分のみ相賞の溜度に加熱世られ，そ礼加ら空中放冷义以 水中等冷せられるためにフイッシュ・スケールを設生せし めるに足るだけの歪を生ずる結果, 稒入後にフイッシュ スケールが現沈ることがある。无の他，火造品に於て は鍛造比に牦關係に，火造溫度々仕上溫度との關係によ つてフィッシュ・スケール䕠生する.

以上の如く, フイッシュスケールは燒入前の内部歪に 基づくものであるから，乙の内部歪を充分に除去してか ら燒入すればこれが紧生を防止することが出來る。郎ち 燒大前に必ず完全焼鈍を行ふことが必献である。嵒入を 繰返へす場合には必ず中閏燒鈍を行ひ又火造品は熆入前

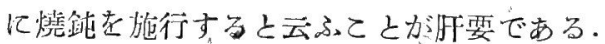

一旦フイッシュスケールを生じをものは普通の䍃頙 のみによつて怙てれを消失せしめるてとは不可能で，炾 鈍によつて一旦はフイッシュスケールは消失するけれ

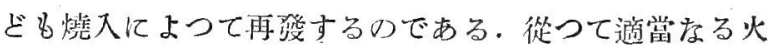

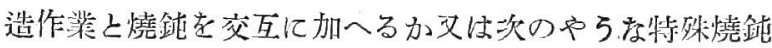
交行ふ上り外飞方法はない。

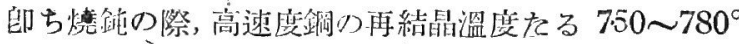
在通過する加熱速度を桠めて䌊徐にするてとが必要で， そのために $600^{\circ}$ 迄徐熱，次いで $650^{\circ}$ の爐に移して

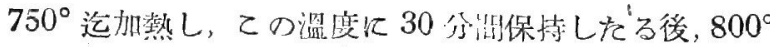
迄 $25^{\circ}$ 飛びに昇溫して各溫度にそれぞれ. 0.5〜1 時阳保 持するやらにする。てのやうにすればフィッシュ・スケー 儿を再湓せしめることはない。

フイッシェスアールを生じを高速度跑仕硬度には俆

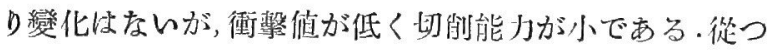
て高速度绸工具の取扱者はフイッシュ・スケールを生ぜ しめないやら，呰入前の除歪操作に意を州ふべきである。 